\title{
Evaluasi Awal Agenda Politik Pemerintahan Baru dan Harapan Rakyat
}

\section{Bambang Cipto}

Susilo Bambang Yudoyono constitutes the first President of Indonesia who has been elected directly by Indonesian people. The election of president directly declares that although democracy in Indonesia still limited, there is cignificant changing in Indonesian political life in particular if this situation compares to before beginning reformation in Indonesia. This article tries to explain the relation management between President and Legislators, this part is so important because for the first time a president becomes the leader of state without strong party supporting. Secondly, the writer describes the crucial problem of the state regarding law enforcement because it is central part of government public relations. The third states welfare of people, the successful or the failure of welfare politic denotes a heavy task for president in new democracy nations.

Kata-kata kunci; manajemen pemerintahan, kepastian hukum, dan kesejahteraan rakyat

To erpilihnya Susilo Bambang Yudoyono dalam pemilihan presiden langsung yang baru pertama kali diselenggarakan di Indonesia merupakan prestasi tersendiri bagi bangsa Indonesia yang oleh bangsa-bangsa di dunia lebih dikenal sebagai "sarang teroris yang tak mampu membangun pemerintahan efektif dalam mengatasi krisis ekonomi." Sampai tingkat tertentu orang Indonesia boleh berbangga dengan capaian saat ini. Akan tetapi, sukses pemilihan presiden langsung ini hanyalah bagian dari rangkaian panjang transisi politik yang sedang dan akan dilalui bangsa ini. Karena walaupun pemilihan presiden langsung relatif dapat dikatakan telah menempatkan politisi sipil pada posisi yang cukup terhormat tetapi mereka tidak memiliki wewenang dan akses untuk mengendalikan militer baik secara personal maupun institusional. Dengan demikian demokrasi di Indonesia masih bersifat terbatas (restricted democracy). ${ }^{2}$
Walaupun demokrasi di Indonesia masih bersifat terbatas, terdapat perubahan signifikan dalam kehidupan politik Indonesia saat ini dibandingkan dengan saat sebelum reformasi. Jika dalam tahun 1999 dan 2001 para politisi di MPR mengawali reformasi dengan memilih presiden yang mereka sukai dan diikuti dengan menggantikan presiden yang tak mereka sukai. Maka tradisi politik ini pun kemudian meluas ke masyarakat luas. Rakyat pemilih di Indonesia dengan berbagai cara dan di tengah perasaan yang campur aduk menjatuhkan hukuman kepada presiden yang sedang berkuasa, Megawati, dan menggantinya dengan presiden baru, Susilo Bambang Yodhoyono. Pemilih Indonesia tampaknya dikecewakan kegagaian Megawati mengangkat derajat wong cilik

1 Lex Rieffel, "Indonesia's Quiet Revolution," Foreign Affairs (September/October 2004)

${ }^{2}$ George Sorensen, Democracy and Democratization: Proceses and Prospects in a Changing World, Boulder, Col: Westview Press, 1993, hal. 47-48. 
sebagaimana sebagaimana janji PDIP. Dalam kenyataan jutaan warga tetap menganggur dan seabrek persoalan yang menindih rakyat kecil terus menumpuk di tengah semakin dekatnya elit PDIP dengan para pengusaha kaya. Pemilihan presiden tahun 2004 menunjukkan bahwa pemilih Indonesia sedikit banyak telah menjadikan pemilihan benar-benar sebagai reward and punishment system. Minimal, keputusan pemilih untuk mendukung Yodhoyono sedikit banyak dipengaruhi oleh ketidakpuasan mereka terhadap kinerja Megawati.

Akan tetapi, kemenangan Yodhoyono dalam pemilihan presiden langsung bukan tidak mungkin lebih merupakan reaksi alamiah rakyat pemilih di tengah atmosfir politik yang mulai terbuka. Namun keputusan para pemilih untuk mendukung Yodhoyono tidak mencerminkan kesadaran komprehensif mereka tentang siapa dan bagaimana dia akan bersikap paska pemilihan presiden atau sejauh mana keputusan untuk memilih Yodhoyono akan memberikan garansi bagi perbaikan nasib mereka. Sebagaimana dikatakan Linz bahwa dalam pemilihan presiden langsung pemilih lebih mampu mengidentifikasi personil calon presiden dan kurang mampu mengenali calon-calon anggota kabinet. ${ }^{3}$ Pemilihan tahap kedua (run off) sudah tentu memperburuk situasi ini.

Dengan memperhatikan kampanye presiden yang dilancarkan pasangan SBYKalla dapat diambil sebuah kesimpulan bahwa mereka sesungguhnya kurang memberikan janji konkret tentang apa yang akan mereka berikan kepada rakyat pemilih. Kata-kata yang secara massif diulang lewat tayangan televisi adalah "Bersama Kita Bisa." Rangkaian kata-kata ini kemudian diperkuat'dengan lagu dan ilustrasi gambar yang menjanjikan impian indah. Akan tetapi, hingga dilantik sebagai presiden Yodhoyono kurang berhasil meyakinkan masyarakat luas bahwa dia memiliki agenda yang jelas. Bagi bangsa miskin seperti Indonesia terlalu banyak persoalan yang menonjol kepermukaan dan sesungguhnya dapat diubah menjadi kebijakan utama pemerintahan baru. Sayang bahwa pada awal pemerintahannya Yodhoyono terlihat mulai mengalami disorientasi arah kebijakan yang diharapkan mampu memperkuat legitimasinya sebagai presiden yang dipilih secara langsung. Tulisan ini akan dibagi menjadi tiga bagian. Bagian pertama membahas tentang manajemen hubungan Presiden dan DPR. Bagian ini sangat penting karena untuk pertama kalinya Presiden memerintah tanpa dukungan partai yang kuat. Bagian kedua membahas tentang keseriusan pemerintahan Yodhoyono dalam menangani kompleksitas persoalan kepastian hukum. Ada kesan bahwa Yodhoyono akan dikondisikan oleh elit lain sehingga gagal memahami upaya menciptakan kepastian hukum sebagai bagian sentral dari government public relations. Bagian ketiga membahas politik kesejahteraan yang merupakan upaya awal presiden terpilih dalam mempertahankan legitimasinya. Keberhasilan dan kegagalan politik kesejahteraan merupakan ujian awal presiden di negara-negara demokrasi baru.

\section{Hubungan Presiden - DPR}

Tak dapat diragukan bahwa Yodhoyono terpilih sebagai presiden dengan legitimasi yang sangat kuat walaupun ia berhadapan dengan presiden Megawati yang didukung

3 Juan.J. Linz, “Democracy, Presidential or Parliamentary: Does it Make a Difference?" dalam Juan J. Linz and Arturo Valenzula, eds. 1994 The Failure of Presidential Democracy: The Case of Latin America, Baltimore: Johns Hopkins University Press, hal. 3-87. 
oleh berbagai kesempatan dan fasilitas yang jauh lebih banyak dan kuat. Akan tetapi, sejak awal terlihat bahwa Yodhoyono sendiri merasakan betapa sulit membentuk pemerintahan yang tidak didukung oleh partai yang berbasis kuat. Kebutuhan untuk membentuk pemerintahan yang kuat dan solid ini merupakan syarat utama sistem demokrasi yang didalamnya badan legislatif memainkan peran penting dalam pembuatan kebijakan publik. Sehingga tanpa pemerintahan yang solid presiden akan sulit menghadapi manuver-manuver DPR bahkan, tidak jarang dapat berakhir pada jalan buntu (deadlock).

Isu pembentukan kabinet secara umum merupakan persoalan dasar yang selalu dihadapi pemerintahan parlementer. ${ }^{4}$ Akan tetapi, isu ini juga menjadi penting di kebanyakan pemerintahan presidensiel di negara-negara demokrasi baru karena sistem presidensiel mereka pada umumnya bertumpu pada sistem multipartai yang pada umumnya terfragmentasi. ${ }^{5}$ Dalam arti bahwa sistem partainya masih sangat lemah atau belum terlembaga. Elit partai tidak terlalu loyal demikian pula para pemilinnya. Tidak heran jika pada sistem demokrasi baru banyak elit partai berpindah partai sementara para pemilih pun sering mengalihkan dukungan mereka dari satu partai ke partai lain dari satu pemilihan ke pemilihan lain. Bahkan dalam kasus Indonesia jauh lebih ekstrim karena dalam dua putaran pemilihan presiden, yang hanya terpaut dua bulan, penyeberangan ke partai lain baik oleh elit maupun para pemilih terjadi dalam skala besar.

Pembentukan kabinet akan menentukan sejauhmana presiden mempersiapkan diri dalam mengelola hubungannya dengan DPR. Secara umum, kabinet yang didukung oleh partai mayoritas akan menghasilkan daya tahan kabinet (cabinet durability) yang cukup tinggi. Daya tahan kabinet ini sangat strategis karena MPR memiliki kekuatan untuk melakukan impeachment terhadap presiden. Dengan sendirinya presiden pun merasa perlu untuk memperkuat basis pendukungnya di DPR. Perlu digarisbawahi bahwa dengan sistem pemilihan langsung sesungguhnya legitimasi presiden sangat ditentukan oleh publik karena presiden mendapatkan legitimasinya bukan dari badan legislatif tapi dari publik pemilih. Dengan kata lain, popularitas presiden dapat dimanfaatkan untuk menghadapi perlawanan DPR. Akan tetapi, mayoritas presiden di negara demokrasi baru pada umumnya belum menyadari dan belum mampu secara maksimal memanfaatkan dukungan publik dalam menghadapi serangan-serangan politik DPR. Sistem politik represif pada masa Suharto membuat publik seakan tidak memiliki kredibilitas yang tinggi di mata para politisi baik di badan legislatif maupun eksekutif. Sehingga presiden pun merasa kurang percaya diri kalau hanya mengandalkan publik dan merasa lebih aman jika mendapatkan dukungan lebih besar dari DPR.

Misinterpretasi sumber kekuatan presiden inilah yang mendasari logika pembentukan kabinet presiden Yodhoyono. Kabinet yang dibentuk terdiri dari para politisi dan profesional yang satu sama lain kurang terikat oleh ideologi dan visi yang mirip satu sama lain. Mereka datang dari latar belakang partai berlainan dan hanya terikat oleh kebutuhan mendapatkan

4. Arend Lijphart, Democracies: Patterns of Majoritarian and Consensus Government in Twenty-one Countries, New Haven and London: Yale University Press, 1984, hal. 67-89.

5 Timothy J. Power, "Parties, Puppets, and Paradox: Changing Attitudes Toward Party Institutionalization in Post-Authoritarian Brazil, Party Politics, Vol 3 (April 1997), hal. 207. 
kekuasaan dan manfaat material sesaat. Sebaliknya; presiden Yodhoyono berharap banyak bahwa para politisi yang direkrutnya sebagai menteri akan menjadikan partai mereka di DPR untuk mendukung pemerintahannya. Akan tetapi, kuatnya gejala disloyalitas politisi sebelum dan sesudah pemilihan presiden putaran kedua merupakan sinyal lemahnya institusi partai politik yang sewaktu-waktu dapat meledak kembali dari dalam tubuh DPR. Pragmatisme berpolitik pada sebagian besar politisi di Indonesia memperkuat asumsi bahwa tidak mudah memprediksi perilaku politik politisi di DPR. Kesulitan menduga perilaku politik DPR dan kecilnya partai politik presiden menumbuhkan isu strategis lain yang sangat besar pengaruhnya dalam manajemen hubungan Presiden dan DPR.

Isu dimaksud adalah kelengkapan alat kekuasaan presiden khususnya jika presiden tergantung pada partai kecil di badan legislatif. Pada masa transisi sukses seorang presiden sangat tergantung pada kemampuannya menghasilkan out put kebijakan yang cepat dirasakan manfaatnya bagi rakyat banyak. Akan tetapi, kebijakan presiden pàda masa transisi tidak selalu didukung DPR. Resiko bagi presiden dengan dukungan partai kecil semakin besar. Untuk mengurangi resiko oposisi DPR dan memperkuat kepastian dukungan DPR beberapa negara demokrasi baru melengkapi presiden dengan kekuasaan konstitusional. Kekuasaan ini dewasa ini dikenal sebagai dekrit presiden (decree power). Dekrit presiden di masa lalu dikenal sebagai bentuk hukum yang cenderung digunakan untuk membubarkan badan legislatif. Presiden Abdurrahman Wahid pernah hampir mengeluarkan dekrit untukk membubarkan DPR yang dipandangnya mengancam kelangsungan dirinya sebagai presiden. Namun MPR bahkan lebih dulu mengambil kebijakan impeachment sehingga Presiden Abdurrahman Wahid akhirnya mundur dari jabatannya sebagai presiden.

Dalam lima belas tahun terakhir pengertian dekrit presiden agak melunak khususnya di negara-negara kawasan Amerika Latin. Dekrit presiden ini memiliki kekuatan hukum walaupun dikeluarkan tanpa mendapatkan izin lebih dahulu dari DPR. ${ }^{6}$ Argentina, Brazil, dan Columbia adalah negara-negara demokrasi baru yang dikenal luas sering menerapkan dekrit presiden. Ruang lingkup dekrit jenis ini sangat terbatas pada sektor kebijakan tertentu, misalnya, sektor pajak, finansial, perdagangan. Di Brazil dekrit presiden cenderung bersifat temporer atau terbatas waktunya sambil menunggu dukungan DPR yang dapat mengubahnya menjadi undangundang yang disahkan DPR. Selama masa menunggu tersebut presiden dapat menjalankan kebijakan sesuai dengan target yang hendak dicapainya.

Sekalipun demikian, pada umumnya kekuasaan untuk mengeluarkan dekrit presiden dijamin oleh konstitusi sehingga dekrit presiden tidak sekedar didorong oleh keinginan presiden memaksakan kehendaknya. Sebaliknya ia sepenuhnya didukung oleh konstitusi. Bidang-bidang yang diliput oleh dekrit presiden berlain-lainan antara satu negara dengan negara lain. Negara tertentu seperti Argentina, memungkinkan presiden mengeluarkan dekrit dalam sektor-sektor ekonomi yang luas. Sementara di negara lain konstitusi membatasi pengeluaran dekrit presiden

6 Matthew Soberg Shugart and Stephan Haggard, "Institutions and Public Policy in Presidential System," dalam Presidents, Parliaments, and Policy, Cambridge: Cambridge University Press, 2001, hal. 72 
pada sektor ekonomi tertentu. Dengan adanya dekrit ini presiden tidak khawatir akan mendapat perlawanan dari DPR selama ia sejalan dengan ketentuan yang diatur konstitusi. Krisis ekonomi Brasil sepanjang dekade 80-an merupakan alasan utama mengapa negara-negara demokrasi Amerika Latin membuka pintu bagi dekrit presiden. Para politisi percaya bahwa dengan didukung dekrit, maka presiden akan lebih percaya diri dalam mencari solusi atas krisis ekonomi yang melilit negara-negara Amerika Latin.

Dalam konteks Indonesia bukan tidak mungkin bahwa presiden terpilih Yodhoyono akan dituntut untuk mengambil kebijakan ekonomi yang tidak populer baik di mata DPR maupun rakyat. Akan tetapi jika kebijakan tersebut diyakini presiden akan meningkatkan kesejahteraan rakyat, maka diperlukan lebih darisekedar dukungan DPR. Krisis ekonomi memerlukan kecepatan gerak dan kekuatan hukum yang cukup untuk meratakan jalan agar tujuan dapat dicapai. Sudah tentu, diperlukan dukungan MPR untuk mengamandemen konstitusi yang memungkinkan presiden mengeluarkan dekrit dengan ruang lingkup terbatas ini.

Langkah Wakil Presiden Kalla merebut posisi Ketua Umum Golkar menimbulkan kontroversi. Publik semakin merasa ditinggalkan dan reformasi munikin akan berjalan lambat dengan duduknya tokoh Golkar dalam posisi yang sangat strategis. Sekalipun demikian, apabila langkah Kalla ini berhenti pada sekedar memperluas dukungan SBY di DPR maka langkah ini tidak maksimal manfaatnya. Sebaliknya, jika langkah ini dilanjutkan dengan fokus perbaikan nasib rakyat maka kekuatan Golkar dapat dimanfaatkan, misainya, untuk melakukan amandemen lanjutan ditingkat MPR. Apakah langkah SBY akan semakin fokus dan strategis pada tahun-tahun selanjutnya masih dapat diperdebatkan lagi. Kebijakan menaikkan harga BBM dan gas adalah satu sinyal bahwa arah kebijäkan SBY kemungkinan belum sungguh-sungguh fokus. Berikut akan bicarakan bagaimana kebijakan ini akan mempengaruhi masa depan SBY dalam lima tahun ke depan.

\section{Politik Kepastian Hukum}

Demokrasi bukan sekedar membentuk partai baru, meningkatkan jumiah politisi sipil, menghapus peran militer dalam politik atau sekedar menyelenggarakan pemilihan umum baik langsung maupun tak langsung. Salah satu inti demokrasi adalah terbentuknya berbagai aturan main yang disepakati bersama oleh rakyat bersangkutan. Aturan main tersebut meliputi aturan main dalam bidang politik, hukum, ekonomi, dan berbagai sektor kehidupan lain. Aturan main atau rules of the game inilah yang menjamin agar permainan atau kegiatan dalam sistem politik demokrasi dapat diramalkan. Walaupun perundingan dan tawar menawar dapat dan selalu diperlukan akan tetapi aturan main dasar perlu disepakati bersama. Salah satu halangan yang memperlambat transisi demokrasi di Indonesia adalah ketiadaan kepastian hukum yang jelas. Kondisi ini membuat jaminan kelancaran kegiatan dan keamanan pribadi maupun kelompok dalam bidangbidang kehidupan sebagaimana disebut diatas menjadi tidak jelas bahkan, pada kasus tertentu jaminan keamanan sering sama sekali tidak ada.

Di samping itu, salah satu keluhan para penanam modal asing di indonesia adalah kesulitan pemerintah sebelum Yodhoyono menciptakan kepastian hukum yang diharapkan akan menjamin kelancaran investasi. Kegagalan pemerintahan Megawati meningkatkan kepastian hukum dengan sendirinya menurunkan minat para 
investor asing. Pemerintahan Yodhoyono dihadapkan pada pilihan antara keharusan meningkatkan kesejahteraan rakyat dan kebutuhan melindungi orang-orang kuat yang selalu lepas dari jerat hukum. Ketidakpastian hukum semakin parah sejak keterbukaan politik bergulir karena masyarakat yang selama ini tidak pernah mendapat kesempatan berpartisipasi memanfaatkan setiap momen yang untuk melabrakkemapanan. Rangkaian kemarahan masyarakat yang tersalur secara normal menimbulkan gelombang protes dan demokrasi yang seakan tak terkendali. Kondisi tidakmenentu inilah yang membuat Indonesia kesulitan membangun kemitraan dengan negara asing yang memerlukan jaminan keamanan.

Persoalan sebenarnya jauh lebih komprehensif daripada sekedar upaya melindungi kepentingan modal asing. Proses demokrasi yang terus berjalan akan terancam mandeg jika pemerintah Yodhoyono tidak segera menyadari adanya kebutuhan mendesak akan sebuah Rechsstaat. Yaitu adanya kepastian hukum yang mengatur kehidupan bangsa dalam mana pemerintah dan aparat negara tunduk dan patuh pada hukum (accountable to the rule of law). ${ }^{7}$. Tanpa adanya rechsstaat warga negara atau yang membutuhkan campur tangan negara akan kesulitan untuk menjalankan hak-hak politiknya. Tanpa adanya kepastian hukum yang kokoh dan dijamin oleh konstitusi maka presiden, menteri, hakim, panglima, dan pejabat pemerintah lain dapat melakukan tindakan yang bertentangan dengan konstitusi yang pada akhirnya berpotensi menghancurkan demokrasi.

Kasus-kasus berikut menunjukkan betapa lemahnya jaminan hukum di Indonesia pada pemerintahan sebelum Yodhoyono. Kasus mantan ketua DPR Akbar
Tanjung barangkali merupakan salah satu kasus hukum yang tunduk pada kemauan politik penguasa, bukan sebaliknya. Kasus konglomerat Tomy Winata vs Majalah Tempojuga memperkuat asumsi bahwa para penegak hukum seringkali jatuh di bawah pengaruh orang-orang kuat. Sementara rakyat yang lemah secara ekonomi dan politik harus mengikuti kemauan penguasa. Terakhir adalah kasus terbunuhnya Munir, seorang pembela Hak Azasi Manusia yang tangguh di atas pesawat Garuda yang terbang menuju Belanda. Hingga kini kasus yang melibatkan pejuang HAM ini semakin kabur dan takjelas siapa yang bertanggungjawab atas kematian Munir. Berbagai kasus lain yang terhitung banyaknya juga tak terungkap.

Gebrakan presiden Yodhoyono dengan menangkap Gubemur Aceh, Abdullah Puteh, barulah sebuah awal yang baik. Akan tetapi tantangan Yodhoyono jauh lebih rumit. Alangkah baiknya kalau pemerintah baru bersedia belajar dari pemerintah Cina yang memandang persoalan korupsi sebagai persoalan strategis. Sudah sejak lama Cina menyadari bahwa pemberantasan korupsi sangat penting karena akan meningkatkan citra Cina dimata intermasional. Oleh karena itu, selama beberapa tahun terakhir pemerintah Cina rajin menjatuhkan hukuman ringan (kurungan) hingga sangat keras (hukuman mati). Kebijakan ini bukan tanpa hasil. Pemerintah Eropa Barat mulai memandang Cina serius dalam membersihkan negaranya-dari tikus-tikus penjarah uang rakyat. Dalam satu bulan terakhir dua orang top leader dari Eropa, berturut-turut Gehrard Schroeder, Kanselir Jerman dan Presiden Perancis Jack Chirac mempererat

7 Juan J. Linz and Alfred Stepan, "Toward Consolidated Democracies," dalam The Global Divergence of Democracies, hal. 98. 
hubungan dagang dengan pemerintah Cina. Bahkan pemerintah Cina menyatakan harapan agar Eropa mencabut embargo pembelian senjata. Meningkatnya daya tarik Cina, antara lain disebabkan oleh transparansi kebijakan anti-korupsi selama

$\therefore$ beberapa tahun, membuat isu pencabutan embargo senjata terhadap Cina menjadi pembicaraan hangat dalam pertemuan anggota European Union di Brussel pada minggu ketiga bulan Desember $2004 .{ }^{8}$

Dengan demikian jelas bahwa pemberantasan korupsi bukan sekedar urusan domestik tapi menyangkut hubungan internasional negara bersangkutan bahkan berdampak pada perekonomian bangsa. Pertemuan Yodhoyono dan Bush dalam pertemuan APEC di Chile beberapa waktu lalu sesungguhnya mengandung manfaat yang perlu dicermati. Dalam pertemuan ini Bush sempat menyinggung pemberantasan korupsi di Indonesia. Yodhoyono sendiri tampaknya cukup bersemangat untuk melakukan sesuatu tentang korupsi sekembalinya dari Chile. Akan tetapi, - :tampaknya masih ada keragu-raguan dalam bertindak sehingga tak segera terdengar sebuah kebijakan anti-korupsi yang bersifat komprehensif. Upaya memenjarakan Abdullah Puteh tidak akan cukup bergaung apalagi dengan bencana yang melanda Aceh pada akhir tahun 2003. Sementara money politics selama Munas Golkar yang melambungkan Kalla ke pucuk pimpinan Golkar $^{9}$ memperkuat dugaan bahwa Yodhoyono tidak serius menangani korupsi.

Upaya pemberantasan korupsi dilakukan Korea Selatan dan Cina dengan cara berbeda dan hasil berlainan pula. Akan tetapi, upaya ini sangat membantu meningkatkan kepastian hukum di kedua negara tersebut. Sehingga di Korea telah tumbuh kekhawatiran di kalangan politisi jika mereka terlibat dalam kasus-kasu korupsi.
Tindakan menghukum mantan presiden atau saudara presiden membuat orang jera melakukan tindakan korupsi. Kini tergantung pada presiden Yodhoyono untuk memulai tindakan konkret dalam pemberantasan korupsi apakah akan tetap ragu-ragu atau segera bertindak cepat untuk menjaga momentum popularitas dirinya selaku presiden. Keterlambatan bertindak dipastikan akan berdampak buruk terhadap popularitasnya. Bencana Aceh dan rangkaian dampaknya bisa jadi akan dimunculkan sebagai alasan untuk menunda upaya memerangi korupsi. Manajemen publik opini di masa Orde Baru tampaknya akan kembali dimainkan sehingga semakin banyak berita tentang dampak sosial-ekonomi paska Tsunami akan dijadikan sebagai kabut yang menutupi kasus-kasus korupsi yang semakin tak terkendali. Bagaimana mungkin korupsi akan berakhir jika Wapres Kalla, sebagaimana disinyalir majalah Gatra, menggunakan cara-cara lama untuk merebut kursi puncak partai Golkar, sebuah contoh buruk yang tentunya akan diikuti oleh yang lain. =

\section{Politik Kesejahteraan Rakyat}

Pasangan SBY-Kalla menjadikan Koalisi Kerakyatan sebagai slogan untuk menarik sebanyak mungkin pendukung. Secara implisit Koalisi Kerakyatan merupakan bagian sentral dari disain kampanye yang diarahkan untukmenetralisir Koalisi Kebangsaan. Akan tetapi, rakyat pemilih lebih suka menerjemahkan makna Koalisi Kerakyatan sebagai kehendak "tulus" pasangan SBY-Kalla yang bermaksud memberi perhatian lebih banyak pada rakyat kebanyakan. Kurang lebih inilah yang terjadi

\footnotetext{
${ }^{8}$ Newsweek, December 2004.

${ }^{9}$ Gatra, 1 Januari 2005
} 
pada saat Megawati melalui PDIP mengkampanyekan slogan "wong cilik" menjelang pemilihan anggota DPR tahun 1999. Slogan ini sempat membumbungkan perolehan kursi Partai Banteng bermulut putih tersebut walaupun saat itu pemilihan presiden masih bersifat tidak langsung. Akan tetapi, slogan "wong cilik" segera lenyap dari kesadaran rakyat justru pada saat Megawati menjabat presiden. Berdasarkan pengalaman di atas bukan tidak mungkin bahwa slogan Koalisi Kerakyatan yang diusung SBY-Kalla akan menghadapi nasib yang sama, ditinggalkan para pecintanya saat Yodhoyono telah resmi memerintah selaku Presiden Republik Indonesia.

Pada masa transisi dan paska krisis ekonomi presiden yang baru terpilih dituntut untuk mampu merumuskan politik kesejahteraan rakyat yang jelas dan fokus baik dalam hal gagasan maupun rencana aksi atau implementasinya. Akan tetapi, bagi pemerintah Yodhoyono pertimbangan jangka panjang agaknya kurang mendapat tempat yang proporsional dalam memahami persoalan bangsa. Sebagai misal, kebijakan menaikkan harga BBM sudah tentu sangat bertentangan dengan jiwa Koalisi Kerakyatan. Fungsi dukungan yang begitu besar dari berbagai elemen masyarakat luas pada saat pemilihan presiden diabaikan sekedar untuk memenuhi tuntutan kelompok kuat yang senantiasa menuntut kemudahan. Kebijakan ini secara eksplisit memperlihatkan ketidakpekaan presiden pada saat dihadapkan dengan persoalan-persoalan kenegaraan yang bersifat riel.

Perlu digarisbawahi disini bahwa legitimasi pemerintahan SBY sebenarnya terbatas masa berlakunya hanya sampai dengan terbentuknya pemerintahan baru, kecuali presiden mampu menghasilkan berbagai prestasi pada tahun-tahun berikutnya. Perlu diingat bahwa pada sistem otoriter (era Suharto) legitimasi dipertahankan dengan cara-cara represif. Dalam sistem demokrasi presidensiel yang presidennya dipilih langsung dan jabatan presiden bersifat tetap (fixed term) bukan berarti bahwa sesudah pemerintah baru terbentuk presiden dapat leluasa mengambil kebijakan. Presiden yang dipilih langsung akan dituntut untuk tetap memelihara popularitasnya (salah satu sumber legitimasi presiden) di kalangan publik karena itulah senjata paling kuat untuk menghadapi lawan dan kawan politiknya selama masa jabatan presiden. Oleh karena itu, perumusan kebijakan yang sangat fundemental dan bersifat transformatif memerlukan kajian mendalam sebelum benar-benar diimplementasikan. Dalam sistem presidensiil baik presiden maupun wapres tak dapat sekedar mengatakan bahwa sebuah kebijakan adalah penting dan mendesak sehingga semua orang harus mendukungnya tanpa syarat. Patut disayangkan bahwa tradisi otoritarianisme tampaknya masih menjadi penggerak utama top executive negeri ini. Serangkaian pernyataan Wapres berkenaan dengan kebijakan kenaikan BBM memperkuat asumsi di atas. Jika model ini terus dipelihara bukan tidak mungkin akan menjadi blunder politik di tengah masa jabatan presiden Yodhoyono.

Politik peningkatan kesejahteraan rakyat adalah persoalan sangat vital bagi kelangsungan sebuah pemerintah baru. Jangankan pada negara-negara demokrasi baru yang sedang berada dalam posisi transisi politik, presiden di negara demokrasi maju pun dituntut untuk menunjukkan komitmen yang tinggi agar politik peningkatan kesejahteraan ini benar-benar terlaksana. Sebagai contoh, calon presiden Clinton yang kemudian hari dikenal sukses dalam meningkatkan kesejahteran rakyat Amerika sangat memperhatikan kondisi 
ekonomi rakyat Amerika di masa akhir pemerintahan presiden Bush (tahun 1992) pertumbuhan ekonomi berjalan di bawah angka $1 \%$. Pertumbuhan ekonomi minus ini menimbulkan banyak PHK dikalangan kelas menengah ke bawah sehingga publik Amerika sangat tidak puas dengan cara kerja Bush walaupun ia dikenal luas sebagai pahlawan perang teluk. ${ }^{10}$ Berdasarkan kenyataan yang sangat memprihatinkan ini calon Presiden Clinton kemudian secara intensif mempersiapkan program peningkatan lapangan kerja besar-besaran. Clinton menjabarkan rencana aksinya dengan berjanji akan menambah jumlah lapangan kerja sebanyak 8 juta orang dan akan menaikkan pajak." Sudah barang tentu politik peningkatan kesejahteraan yang diagendakan Clinton tidak datang tiba-tiba saat ia terpilih sebagai presiden. Akan tetapi, telah dibicarakan secara luas dan mendalam sepanjang masa kampanye sehingga cukup banyak lapisan masyarakat yang memahami arah kebijakan tersebut. Dengan demikian, kebijakan ini telah mendapatkan legitimasi dalam proses pengolahan selama masa kampanye. Sukses politik kesejahteraan Clinton terletak pada masa sosialisasi yang cukup waktu, proses diskusi publik yang cukup lama sebelum akhirnya ia terpilih sebagai presiden. Hanya dalam waktu dua tahun 4 juta lapangan kerja berhasil diciptakan pemerintahan Clinton

Sebaliknya, pada masa kampanye pemilihan presiden rakyat Indonesia sedikit sekali mendapatkan informasi atau sinyal dari pasangan SBY-Kalla tentang yang akan mereka lakukan dengan sungguh-sungguh. Tidak terlihat adanya jabaran agenda yang menyeluruh dan mendalam dan berdampak pada perilaku rakyat pemilih, sebagaimana disebutkan di atas bahwa pemilih mengalihkan dukungan dari Megawati ke
Yodhoyono lebih karena harapan baru plus unsur kebosanan terhadap presiden yang sedang berkuasa (incumbent president) yang menggejala di sejumlah besar negaranegara demokrasi baru. Bahkan, sepanjang kampanye tidak pernah sekalipun muncul pemikiran tentang kenaikan harga BBM yang dampaknya akan sangat besar bagi kehidupan rakyat kecil.

Dengan menaikkan harga BBM pada awal pemerintahannya sangat jelas bahwa komitmen pemerintah baru untuk meningkatkan kesejahteraan rakyat, sebagaimana tercermin dari slogan Koalisi Kerakyatan, sangat rendah atau bahkan sama sekali tidak ada. Lebih jauh dapat dikatakan bahwa perumusan kebijakan kenaikan BBM yang seakan-akan bersifat darurat mengindikasikan adanya dua hal. Pertama, kemungkinan besar ini merupakan program tersembunyi (hidden agenda) karena datang dengan tiba-tiba. Proses pengambilan keputusan semacam ini sangat tidak sesuai dengan cita-cita demokrasi khususnya pada masa transisi. Kedua, dengan memaksa publik menerima kebijakan kenaikan harga BBM di tengah tingginya pengangguran, kriminalitas, narkoba, biaya sekolah, dan isu-isu TKW menunjukkan irasionalitas proses pembuatan kebijakan publik yang menyangkut kepentingan rakyat banyak.

Bandingkan, misalnya, dengan Clinton yang menawarkan program penciptaan lapangan kerja untuk mengatasi pengangguran yang menumpuk. Tawaran program calon presiden Clinton merupakan jawaban

${ }^{10}$ Lee. H. Hamilton," A Democrat Looks At Foreign Policy," Foreign Policy, Summer 1992, hal. 36.

"Stanley B. Greenberg, "The Mythology of Centrism: Why Clinton and Blair Really Won," The American Prospect, Vol. 8, Issue 34 (September - October 1997). 
logis dari persoalan riil pengangguran akibat turunya tingkat pertumbuhan ekonomi. Sementara, kebijakan kenaikan harga BBM dengan alasan subsidi hanya dinikmati orang-orang kaya adalah sebuah mispersepsi atas persoalan riil. Bagaimana mungkin seseorang harus membayar mahal harga BBM sementara lapangan kerja sangat sulit dicari dan biaya pendidikan mencekik leher, biaya kesehatan pun semakin tak terjangkau? Kebijakan publik yang disusun berdasarkan mispersepsi-mispersepsi semacam ini "political cost-nya" sangat tinggi. Orang akan memahami jika pemerintah bermaksud mengatur sistem pendidikan nasional sehingga anak-anak muda dipermudah untuk sekolah atau melanjutkan ke perguruan tinggi. Publik akan berterima masih bila biaya perawatan disubsidi dengan perencanaan yang jelas. Akan tetapi, publik sangat sulit menerima jika subsidi BBM akan disalurkan untuk pendidikan dan kesehatan sementara programya tidak jelas.

Barangkali Indonesia perlu belajar dari pemerintahan Chile yang di saat transisi berhasil merebut perhatian publik dengan merumuskan dan mengimplementasikan kebijakan sesuai dengan denyut jantung dan suara hati rakyatnya. Alih-alih merumuskan kebijakan yang sangat berpotensi membebani rakyat, pemerintah Chile justru memikirkan cara untuk meningkatkan belanja sosial guna meningkatkan kesejahteraan sosial. Kebijakan ini ditempuh dengan menaikkan pajak. Melalui serangkaian tawar-menawar dan perundingan dengan badan legislatif akhirnya pemerintah Chile memanfaatkan hasil kenaikan pajak tersebut untuk peningkatan pelayanan kesehatan dan pendidikan rakyăt. ${ }^{12}$ Sepanjang pemerintahan Suharto, isu kenaikan pajak jarang muncul ke permukaan. Pemerintah lebih suka menaikkan harga BBM walaupun dampaknya selalu menaikkan semua harga barang karena mulai dari produksi, distribusi, hingga transportasi terkena dampak kenaikan BBM. Hingga saat ini belum ada pemerintah Indonesia yang mampu menghentikan dampak langsung dari kenaikan BBM. Satu hal pasti bahwa tingkat kesejahteraan rakyat justru akan semakin buruk akibat naiknya harga BBM. Politik kesejahteraan rakyat pemerintah Yodhoyono perlu ditinjau kembali sedalam-dalamnya karena selama ini tidak pernah menyelesaikan persoalan. Bukan tidak mungkin bahwa dengan meniru Chile Indonesia akan memasuki era baru perubahan politik kesejahteraan dengan dampak yang tidak terlalu besar bagi rakyat kecil.

\section{Penutup}

Pada awal pemerintahannya, Yodhoyono tampak berusaha keras membangun koalisi dengan berbagai elit partai pendukungnya dan dilanjutkan dengan upaya merebut suara Golkar di DPR melalui Yusuf Kalla. Manuver-manuver awal ini mencerminkan rendahnya rasa percaya diri Yodhoyono dalam menge-lola hubungan eksekutif-legislatif yang merupakan sumber potensi konflik paling besar bagi kelangsungan dirinya sebagai presiden. Pengalaman presiden Abdur-rahman Wahid menjadi salah satu dorongan utama bagi Yodhoyono untuk memperkuat basis dukungan di DPR./MPR. Sekalipun demikian upaya ini tidak akan cukup karena

12 Jorge L. Dominguez, "Free Politis and Free Markets in Latin Amerika," dalam The Global Divergence of Democracies, diedit oleh Larry Diamond and Marc F. Plattner, Maryland: The John Hopkins University Press and the National Endowment for Democracy, 2001, hal. 250 
pada masa transisi setiap negara demokrasi menghadapi persoalan-persoalan yang datang secara simultan dan memeriukan solusi yang simultan pula. Oleh karena itu, diperlukan kelengkapan berbasis konstitusi berupa kekuasaan untuk mengeluarkan dekrit, khusus dalam sektor-sektor ekonomi, yang sayangnya kurang dikenal di Indonesia. Dengan sumber kekuasaan presiden yang relatif terbatas (rendahnya apresiasi politisi terhadap pendapat umum/ hasil polling dan tak adanya back up konstitusi bagi presiden untuk mengambil keputusan kontroversial) maka konflik eksekutif-legislatif diperkirakan masih akan muncul menghadang kemajuan pemerintahan Yodhoyono.

Politik kepastian hukum atau pembentukan rechsstaat sudah semakin mendesak untuk segera dilakukan. Kebijakan pemerintah sebelumnya yang cenderung menundukkan hukum terhadap kekuasaan mendorong penyalahgunaan kekuasaan di berbagai lapisan pemerintahan dari pusat hingga daerah. Ketiadaan kepastian hukum dalam berbagai sektor kehidupan telah menurunkan citra Indonesia di mata internasional. Dampaknya bangsa ini mulai ditinggalkan para investor asing. Sungguh ironis bahwa negara semakmur Cina berusaha keras agar Eropa meningkatkan investasinya ke negeri tersebut, sementara kita yang sangat miskin di antara negara-negara Asia' Tenggara bahkan tidak cemas saat para investor berlarian. Bagaimana mungkin Indonesia dapat memelihara kredibilitasnya di mata internasional jika para koruptor kelas kakap dibiarkan berkeliaran sementara para aktifis HAM justru ketakutan terhadap keamanan diri mereka? Tanpa kebijakan penataan kepastian hukum yang bijak dan berorientasi ke depan sulit bagi bangsa ini untuk merebut kembali kredibilitasnya di mata inter- nasional.

Terakhir, politik kesejahteraan rakyat yang secara tak langsung tercermin dari makna Koalisi Kerakyatan semakin hari semakin berkurang maknanya. Kebijakan menaikkan harga BBM yang merupakan kebiasaan lama tetap dijalankan padahal semua orang tahu bahwa rakyat kecil adalah korban pertama dari politik semacam ini. Kebijakan ini mencerminkan rendahnya kepekaan pemerintahan Yodhoyono terhadap psikologi rakyat Indonesia. Kebijakan ini juga mencerminkan kegagalan Yodhoyono memahami makna pemilihan presiden langsung yang di negara industri maju pun dimanfaatkan untuk promosi kebijakan peningkatan kesejahteraan rakyat. Sangat disayangkan bahwa pemerintahan Yodhoyono menjadikan aspek peningkatan kesejahteraan rakyat hanya dalam bentuk janji tanpa rencana yang rinci dan matang sehingga rakyat pun menjadi ragu apakah harapan mereka akan terpenuhi.

Tampakya sukses pemilihan presiden saja tidak cukup untuk mengawali sebuah pemerintahan baru. Sebaliknya pemahaman yang jelas tentang persoalan dasar masyarakat, kemampuan membangun koalisi, pemahaman dan kemampuan memanfaatkan sumber-sumber kekuasaan presiden, selain dukungan tradisional dari DPR adalah serangkaian kapasitas yang harus dimiliki presiden dan kabinetnya. Jika pemahaman dan kemampuan implementasi dari persoalan-persoalan di atas diabaikan dan hanya sekedar menjalankan politik sebagai kegiatan rutin maka pemerintahan ini akan menghadapi kesulitan besar. 


\section{Daftar Pustaka}

Arend Lijphart, 1984, Democracies: Patterns of Majoritarian and Consensus Government in Twentyone Countries, New Haven and London: Yale University Press.

\section{Gatra, 1 Januari 2005}

George Sorensen,1993, Democracy and Democratization: Proceses and Prospects in a Changing World, Boulder, Col: Westview Press.

Jorge L. Dominguez, "Free Politis and Free Markets in Latin Amerika," dalam The Global Divergence of Democracies, diedit oleh Larry Diamond and Marc F. Plattner, Maryland: The John Hopkins University Press and the National Endowment for Democracy, 2001.

Juan J. Linz and Alfred Stepan,1994, "Toward Consolidated Democracies," dalam The Global Divergence of Democracies.

Juan J. Linz,1994, "Democracy, Presidential or Parliamentary: Does It Make a Difference?" dalam Juan J. Linz and Arturo Valenzula, eds. The Failure of
Presidential Democracy: The Case of Latin America, Baltimore: Johns Hopkins University Press.

Lee. H. Hamilton, 1992," A Democrat Looks At Foreign Policy," Foreign Policy, Summer 1992.

Lex Rieffel, "Indonesia's Quiet Revolution," Foreign Affairs (September/October 2004)

Matthew Soberg Shugart and Stephan Haggard,2001, "Institutions and Public Policy in Presidential System," dalam Presidents, Parliaments, and Policy, Cambridge, Cambridge University Press.

Newsweek, December 2004.

Stanley B. Greenberg, "The Mythology of Centrism: Why Clinton and Blair Really Won," The American Prospect, Vol. 8, Issue 34 (September-October 1997).

Timothy J. Power, 1997, "Parties, Puppets, and Paradox: Changing Attitudes Toward Party Institutionalization in Post-Authoritarian Brazil, Party Politics, Vol 3 (April 1997). 